\title{
HUBUNGAN TINGKAT PENERIMAAN MASYARAKAT DENGAN TINGKAT LIVABILITY PERMUKIMAN KAMPUNG DERET PETOGOGAN DAN KAMPUNG DERET KAPUK
}

\author{
Bella Prita Cahyani, Deni Agus Setyono, Wulan Dwi Purnamasari \\ Jurusan Perencanaan Wilayah dan Kota, Fakultas Teknik, Universitas Brawijaya \\ Jl. Mayjend Haryono 167 Malang 65141 - Telp (0341)567886 \\ e-mail: bellaprita.cahyani@gmail.com
}

\begin{abstract}
ABSTRAK
Program Kampung Deret merupakan salah satu upaya penanganan permukiman kumuh yang dilakukan oleh Gubernur Provinsi DKI Jakarta melalui kebijakan Peraturan Gubernur Nomor 64 Tahun 2013 yang berisi Bantuan Perbaikan Rumah di Permukiman Kumuh Melalui Penataan Kampung. Terdapat dua kawasan permukiman yang keduanya mendapat program Kampung Deret dari Pemerintah Daerah DKI Jakarta namun dengan kondisi fisik lingkungan yang berbeda yaitu Kampung Deret Petogogan dan Kampung Deret Kapuk. Tujuan penelitian adalah untuk mengidentifikasi hubungan antara tingkat penerimaan masyarakat terhadap program Kampung Deret dengan tingkat livability permukiman Kampung Deret Petogogan dan Kampung Deret Kapuk. Analisis yang digunakan adalah analisis tingkat penerimaan masyarakat dan analisis tingkat livability. Secara keseluruhan tingkat penerimaan di Kampung Deret Petogogan memperoleh klasifikasi setuju dan Kampung Deret Kapuk memperoleh klasifikasi sangat setuju dan setuju. Analisis tingkat livability melibatkan teknik skoring dan AHP. Bobot tertinggi yang didapatkan dari AHP adalah ketersediaan air bersih. Penilaian tingkat livability didapatkan dari perkalian skoring kesesuaian lingkungan dengan bobot AHP, secara keseluruhan klasifikasi tingkat livability untuk kedua kampung adalah tinggi. Hasil dari analisis chi square ditemukan adanya hubungan yang lemah antara tingkat penerimaan masyarakat dengan tingkat livability di Kampung Deret Petogogan dan tidak ditemukan adanya hubungan di Kampung Deret Kapuk.
\end{abstract}

Kata Kunci: Program Kampung Deret, Tingkat Penerimaan, Tingkat Livability

\section{ABSTRACT}

The Kampung Deret program is one of the efforts to deal with slum settlements carried out by the Governor of DKI Jakarta Province through a policy of Governor Regulation Number 64 of 2013 which contains Support for Home Improvement in Slum Settlements through Village Planning. There are two residential areas, both of them was received the Kampung Deret program from the Regional Government of DKI Jakarta but with different environmental physical conditions, that was Kampung Deret Petogogan and Kampung Deret Kapuk. The research objective was to identify the relationship between the level of community acceptance of the Kampung Deret program and the level of livability of the Kampung Deret Petogogan and Kampung Deret Kapuk. The analysis used is the level of public acceptance analysis and level of livability analysis. Overall the level of acceptance in Kampung Deret Petogogan was classified as agree and Kampung Deret Kapuk was classified as very agree and agree. Level of livability analysis involves scoring techniques and AHP. The highest weight obtained from AHP is the availability of clean water. Assessment of livability level was obtained from environmental suitability scoring with AHP weighting, overall classification of livability level for both Kampung Deret was high. The results of the chi-square analysis found a weak relationship between the level of community acceptance and the level of livability in Kampung Deret Petogogan and no relationship was found in Kapuk Village.

Keywords: The Kampung Deret Program, Level of acceptance, Level of livability

\section{PENDAHULUAN}

Kepadatan penduduk yang tinggi menyebabkan minimnya ketersediaan lahan untuk penyediaan tempat tinggal atau permukiman untuk masyarakat yang menyebabkan munculnya permukiman kumuh. Tingginya kepadatan penduduk tidak terlepas dari perkembangan kota yang juga semakin meningkat. Dengan kepadatan penduduk yang tinggi, maka Pemprov DKI Jakarta melakukan program penataan permukiman kumuh berbasis masyarakat melalui pembangunan Kampung Deret di sejumlah lokasi yang digerakkan semenjak tahun 2013 dengan tujuan mengatasi masalah hunian kumuh di perkotaan yang kian meluas (Setiadi, 2016).

Program Kampung Deret merupakan salah satu upaya penanganan permukiman kumuh yang dilakukan oleh Gubernur Provinsi DKI Jakarta melalui kebijakan Peraturan Gubernur Nomor 64 Tahun 2013 yang berisi "Bantuan Perbaikan Rumah di Permukiman Kumuh Melalui Penataan Kampung". Program Kampung Deret merupakan program perbaikan permukiman kumuh yang menerapkan peremajaan dalam penerapannya. Peremajaan merupakan kegiatan perombakan 
dengan perubahan yang mendasar dan bersifat menyeluruh dalam suatu kawasan agar kawasan tersebut menjadi lebih tertata, terencana, dan tertib (Dirjen Perumahan dan Permukiman, 2001). Kegiatan peremajaan ini dapat sejalan dengan RPJPN Tahun 2005-2025 yang mempunyai target yaitu Pemenuhan Standar Pelayanan Perkotaan (SPP) menuju Kota Layak Huni. Dengan adanya program Kampung Deret yang mempunyai pola penanganan peremajaan akan dapat memenuhi SPP menuju Kota Layak Huni yang dapat diukur dengan indikator livability.

Kampung Deret Petogogan yang berlokasi di Kota Jakarta Selatan yang tepatnya terletak di Kelurahan Petogogan, Kecamatan Kebayoran Baru adalah salah satu dari banyak permukiman kumuh yang diberi bantuan program dari Pemerintah Provinsi DKI Jakarta berupa perbaikan kawasan menjadi kampung deret pada tahun 2013. Pemberian program perbaikan kawasan dari Pemerintah menandakan bahwa Kelurahan Petogogan merupakan kawasan prioritas penanganan di Kota Jakarta Selatan. Menurut hasil penelitian evaluasi pasca huni yang membahas keberhasilan program Kampung Deret Petogogan yang menggunakan pendekatan evaluasi pasca huni, program tersebut tergolong sukses, dikarenakan dari 25 variabel yang ada, 23 variabel tergolong "Memuaskan" (Setiadi et al, 2016).

Selanjutnya menurut data Evaluasi RW Kumuh, DKI Jakarta tahun 2013, ditemukan sejumlah $223 \mathrm{RW}$ yang tergolong kumuh. Enam di antaranya berlokasi di Kelurahan Kapuk, Kecamatan Cengkareng, Jakarta Barat. Permukiman di kelurahan tersebut sudah mendapat program terkait dengan peningkatan kualitas lingkungan kumuh yaitu program Kampung Deret. Namun program tersebut belum memberikan hasil signifikan terhadap Kampung Deret Kapuk (Fitria et al, 2014). Program Kampung Deret di Jakarta Barat juga dinilai gagal karena adanya penyusutan jumlah unit rumah yang direnovasi sebesar $100 \%$ dari program kampung deret lainnya. Kampung Deret Kapuk dengan jumlah target perbaikan rumah adalah 200 unit namun hanya 90 unit rumah yang terealisasi (Hasil Survei Primer, 2018).

Terdapat dua kawasan permukiman yang keduanya mendapat program perbaikan lingkungan yang berupa program Kampung Deret dari Pemerintah Daerah DKI Jakarta namun dengan kondisi fisik lingkungan yang berbeda yaitu Kampung Deret Petogogan dan Kampung Deret Kapuk. Terdapat hubungan antara keberhasilan dari penerapan suatu program dengan tingkat penerimaan atau tingkat kepuasan penerima program tersebut (Poblete dalam Setiadi 2016). Maka dengan perbedaan kondisi eksisting antara kedua kampung seperti yang telah dijelaskan sebelumnya, diperlukan pengukuran tingkat penerimaan masyarakat sebagai penerima program Kampung Deret untuk mengetahui hasil dari program tersebut berdasarkan persepsi dari masyarakat. Program Kampung Deret dapat dikatakan merupakan salah satu program implementasi dari RPJPN Tahun 2005-2025 yang mempunyai target yaitu Pemenuhan Standar Pelayanan Perkotaan (SPP) menuju Kota Layak Huni yang dapat diukur menggunakan tingkat livability. Dari permasalahan yang telah diuraikan, maka diperlukan adanya penelitian untuk mengetahui tingkat penerimanaan masyarakat, tingkat livability permukiman, serta hubungan atara tingkat penerimaan masyarakat terhadap program Kampung Deret dengan tingkat livability permukiman antara Kampung Deret Petogogan dan Kampung Deret Kapuk.

\section{METODE PENELITIAN}

Penelitian pengaruh tingkat penerimaan masyarakat terhadap tingkat livability permukiman kampung deret petogogan dan kampung deret kapuk menggunakan teknik deskriptif kuantitatif. Metode kuantitatif digunakan untuk mencapai setiap tujuan yang ada. Penelitian ini menggambarkan secara kuantitatif tingkat penerimaan masyarakat serta tingkat livability permukiman.

\section{Variabel Penelitian}

Variabel yang digunakan dalam penelitian ini didasarkan pada teori terkait tingkat penerimaan masyarakat serta tingkat livability permukiman. Variabel tingkat penerimaan masyarakat mengacu pada teori menurut Davis (1989) yang dijabarkan oleh Joubert (2015) dan variabel tingkat livability yang mengacu pada IAP (2009) yang dijabarkan oleh Muttaqin (2010). Variabel penelitian dapat dilihat pada Tabel 1.

\section{Tabel 1. Variabel Penelitian}

\begin{tabular}{|c|c|c|}
\hline & & \\
\hline & & \\
\hline & \multirow{4}{*}{$\begin{array}{l}\text { Variabel } \\
\text { Persepsi } \\
\text { manfaat }\end{array}$} & \multirow{4}{*}{ 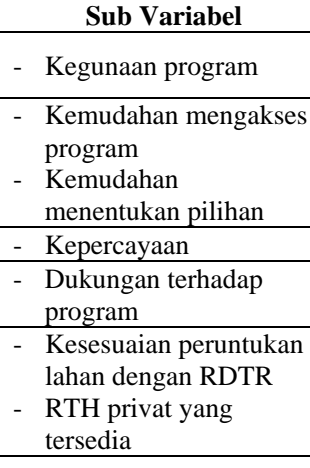 } \\
\hline & & \\
\hline & & \\
\hline \begin{tabular}{l}
\multicolumn{1}{c}{ Tujuan } \\
Mengukur tingkat \\
penerimaan \\
masyarakat \\
Kampung Deret \\
Petogogan dan \\
Kampung Deret \\
Kapuk terhadap \\
program Kampung \\
Deret \\
Mengukur tingkat \\
livability \\
permukiman \\
Kampung Deret \\
\end{tabular} & & \\
\hline
\end{tabular}




\begin{tabular}{|c|c|c|}
\hline $\begin{array}{l}\text { Tujuan } \\
\end{array}$ & Variabel & Sub Variabel \\
\hline \multirow{6}{*}{$\begin{array}{l}\text { Petogogan dan } \\
\text { Kampung Deret } \\
\text { Kapuk }\end{array}$} & $\begin{array}{l}\text { Kualitas } \\
\text { lingkungan }\end{array}$ & $\begin{array}{l}\text { - Upaya pengelolaan } \\
\text { sampah }\end{array}$ \\
\hline & $\begin{array}{l}\text { Transportasi- } \\
\text { aksesibilitas }\end{array}$ & $\begin{array}{l}\text { - Ketersediaan angkutan } \\
\text { umum } \\
\text { - Kesesuaian dimensi } \\
\text { jalan }\end{array}$ \\
\hline & Fasilitas & $\begin{array}{l}\text { Aksesibilitas menuju } \\
\text { fasilitas kesehatan } \\
\text { - Aksesibilitas menuju } \\
\text { fasilitas pendidikan }\end{array}$ \\
\hline & Utilitas & $\begin{array}{l}\text { - } \text { Ketersediaan air bersih } \\
\text { - Ketersediaan utilitas } \\
\text { listrik } \\
\text { - Kualitas pelayanan air } \\
\text { bersih } \\
\text { - Kualitas pelayanan } \\
\text { jaringan listrik } \\
\end{array}$ \\
\hline & Ekonomi & - Lapangan pekerjaan \\
\hline & Sosial & - Interaksi sosial \\
\hline \multirow{3}{*}{\begin{tabular}{lr}
\multicolumn{2}{l}{ Mengidentifikasi } \\
hubungan antara \\
tingkat penerimaan \\
masyarakat \\
terhadap program \\
Kampung & Deret \\
dengan & tingkat \\
livability & \\
permukiman & \\
Kampung & Deret \\
Petogogan & dan \\
Kampung & Deret \\
Kapuk & \\
\end{tabular}} & $\begin{array}{l}\text { Tingkat } \\
\text { penerimaan } \\
\text { masyarakat }\end{array}$ & 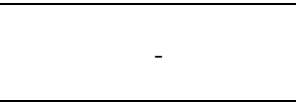 \\
\hline & Tingkat & \\
\hline & livability & \\
\hline
\end{tabular}

\section{Metode Pengumpulan Data}

Metode pengumpulan data yang digunakan yaitu dengan survei primer dan sekunder. Data primer yang dibutuhkan dilakukan dengan kuesioner dan observasi. Kuesioner yang disebarkan untuk masyarakat guna memenuhi data untuk tingkat penerimaan masyarakat terhadap program serta Observasi digunakan untuk memenuhi kebutuhan data variabel-variabel tingkat livability permukiman dan. Data sekunder yang digunakan berupa kebijakan, data statistik, serta shapefile guna memenuhi kelengkapan data yang diperoleh dari instansi pemerintahan.

\section{Sampel}

Penelitian ini menggunakan teknik sampling simple random sampling yang kemudian diproporsikan ke RT di masing-masing wilayah studi. Jumlah sampel akan akan diproporsikan di setiap RT sesuai banyaknya jumlah rumah di RT tersebut. Populasi pada penelitian adalah seluruh unit bangunan yang ada di Kampung Deret Petogogan sejumlah 111 unit bangunan dan Kampung Deret Kapuk sejumlah 90 unit bangunan. Jumlah sampel penelitian ditentukan menggunakan tabel Isaac dan Michael yang didapatkan sejumlah 89 unit bangunan untuk Kampung Deret Petogogan dan 62 unit bangunan untuk kampung Deret Kapuk.

\section{Metode Analisis}

\section{1) Analisis Tingkat Penerimaan Masyarakat}

Analisis tingkat penerimaan masyarakat adalah tahapan untuk mengukur variabel kualitatif dengan menentukan aspek penerimaan masyarakat yang ditentukan oleh persepsi manfaat, persepsi kemudahan, sikap, dan keinginan (Fred D. Davis, 1989 dalam Joubert, 2015). Sub variabel tersebut masih bersifat umum, sehingga diperlukan penjabaran setiap sub variabel untuk memudahkan dalam analisis tingkat penerimaan masyarakat berupa indikator. Setelah diketahui indikator dari masing-masing variabel tingkat penerimaan masyarakat, kriteria tersebut dituangkan dalam kuesioner yang selanjutnya dapat dinilai oleh masyarakat dengan bobot dari penilaian skala likert.

\section{2) Analisis Tingkat Livability}

Penilaian kesesuaian livability permukiman menggunakan metode skoring untuk mendapat nilai masing-masing aspek, selanjutnya menggunakan AHP untuk mengetahui bobot yang akan dikalikan nilai pada masing-masing aspek dan pengaruhnya dalam membentuk livability permukiman. Berikut adalah rumus untuk mendapatkan tingkat livability permukiman:

Livability $=$ Skoring Kesesuaian $\mathrm{x}$ bobot AHP (1)

Pada teknik skoring, masing-masing nilai tiap subvariabel mengacu pada peraturan dan standar terkait. Selanjutnya pada teknik AHP, metode ini membutuhkan data yang diperoleh dari kuesioner yang ditujukan kepada para ahli di bidang permukiman maupun pemerintah terkait.

\section{3) Analisis Hubungan Penerimaan Masyarakat Terhadap Livability Permukiman}

Penelitian ini mencari hubungan antara penerimaan masyarakat terhadap livability permukiman antara dua Kampung Deret, yaitu Kampung Deret Petogogan dan Kampung Deret Kapuk. Untuk itu maka digunakan tabulasi silang atau crosstab yang dilanjutkan dengan chi-square. Dasar pengambilan keputusan apakah terdapat hubungan antara tingkat penerimaan masyarakat dan tingkat livability permukiman adalah x pada tabel. Adapun ketentuan dalam pembuktiannya adalah apabila $\mathrm{x}$ hitung lebih besar daripada $\mathrm{x}$ tabel maka dapat diartikan bahwa ada hubungan 
antara tingkat penerimaan masyarakat dengan tingkat livability permukiman dan sebaliknya. Setelah didapatkan hasil keberadaan hubungan antara dua variabel, selanjutnya mencari koefisien kontingensi yang bertujuan untuk mengetahui kekuatan hubungannya (Janah, 2014).

Tabel 2. Kekuatan Hubungan Korelasi

\begin{tabular}{cc}
\hline Interval Korelasi & $\begin{array}{c}\text { Tingkat } \\
\text { Hubungan }\end{array}$ \\
\hline$<0,2$ & Sangat Kecil \\
\hline $0,2-0,4$ & Kecil \\
\hline$>0,4$ & Cukup \\
\hline
\end{tabular}

\section{HASIL DAN PEMBAHASAN}

\section{Gambaran Umum Program Kampung Deret}

Kampung Deret Provinsi DKI Jakarta merupakan program yang dimaksudkan untuk memperbaiki rumah di permukiman kumuh melalui penataan kampung. Program Kampung Deret tercipta karena adanya Peraturan Gubernur Provinsi DKI Jakarta No. 64 Tahun 2013 tentang perbaikan rumah di permukiman kumuh melalui penataan kampung. Program Kampung Deret dilaksanakan di bawah wewenang Suku Dinas Perumahan DKI Jakarta pada tahun 2013. Selain Suku Dinas Perumahan, yang terlibat dalam pelaksanaan adalah Satuan Kerja Perangkat Daerah (SKPD) serta kelompok masyarakat yang menjadi penerima program Kampung Deret. Sebelumnya dilaksanakan sosialisasi dari Suku Dinas Perumahan sebelum dilaksanakan program Kampung Deret. Sosialisasi yang dilakukan adalah memaparkan tujuan pembangunan kampung deret sekaligus diskusi antar masyarakat dan pemerintah. Selain pemaparan maksud dan tujuan, pemerintah juga mensosialisasikan menggunakan media gambar desain bangunan yang akan dibangun untuk para penerima program Kampung Deret. Jangka waktu pelaksanaan Kampung Deret yang ditargetkan oleh pemerintah idealnya adalah 3 bulan. Untuk pendanaan program Kampung Deret yang akan diterima oleh masing-masing penerima program adalah sebesar Rp. 54.000.000 yang dihitung berdasarkan luas rumah penerima program maksimal $36 \mathrm{~m}^{2}$.

\section{Gambaran Umum Wilayah Studi}

\section{1) Kampung Deret Petogogan}

Kelurahan Petogogan terletak di Kecamatan Kebayoran Baru, Kota Jakarta Selatan. Adapun batas wilayah Kelurahan Petogogan adalah sebagai berikut:
Sebelah Utara : Kelurahan Rawa Barat

Sebelah Selatan: Kelurahan Pulo

Sebelah Barat : Kelurahan Melawai

Sebelah Timur : Kecamatan Mampang Prapatan

Kampung Deret Petogogan terletak di 4 RT tepatnya di RT 8, RT 10, RT 11, dan RT 12 yang berada di RW 5. Total unit bangunan yang ada di Kampung Deret Petogogan berjumlah 111 unit rumah.

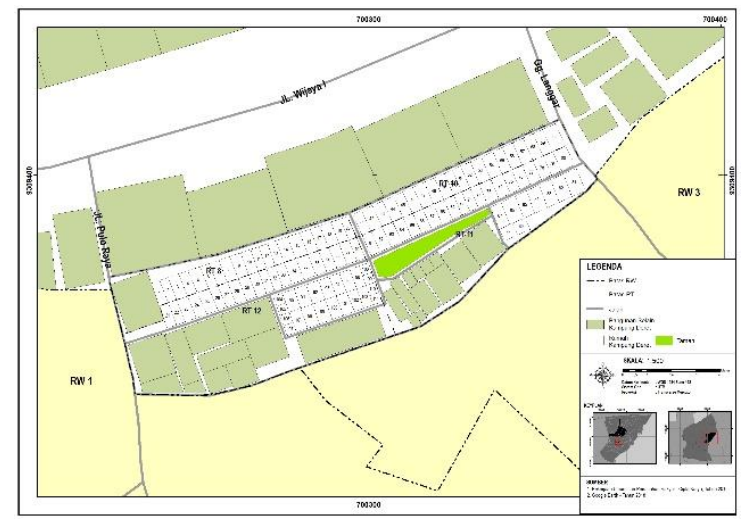

Gambar 1. Peta Administrasi Kampung Deret Petogogan

\section{2) Kampung Deret Kapuk}

Kelurahan Kapuk terletak di Kecamatan Cengkareng, Kota Jakarta Barat.

Adapun batas wilayah Kelurahan Kapuk adalah sebagai berikut:

Sebelah Utara : Kelurahan Kamal Muara

Sebelah Selatan: Kelurahan Cengkareng Timur

Sebelah Barat : Kelurahan Cengkareng Timur

Sebelah Timur : Kelurahan Kedaung Kali Angke

Kampung Deret Kapuk tersebar di 3 RT tepatnya di RT 2, RT 3, dan RT 5 yang terletak di RW 4. Total unit bangunan yang menerima program Kampung Deret Kapuk berjumlah 75 unit rumah.

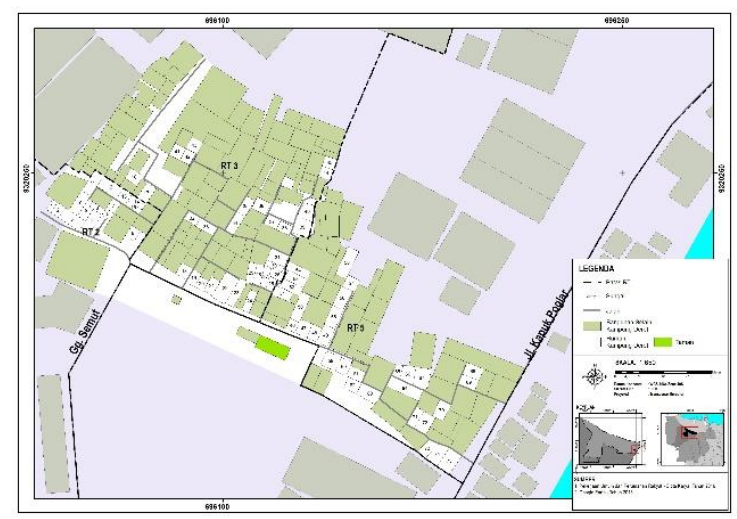

Gambar 2. Peta Administrasi Kampung Deret Kapuk 


\section{Analisis Tingkat Penerimaan Masyarakat}

Penerimaan masyarakat dibahas pada penelitian ini untuk mengetahui penerimaan masyarakat terhadap program dibahas melalui 4 variabel yang terdiri dari 10 indikator yang selanjutnya ditanyakan kepada masyarakat. Penggambaran penerimaan masyarakat digambarkan dengan skala likert lima dimensi dengan persepsi sesuai masing-masing variabel.

Seluruh variabel kemudian dianalisa menggunakan rata-rata untuk menggambarkan penerimaan masyarakat terhadap program setiap variabel pada setiap RT di Kampung Deret Petogogan dan Kampung Deret Kapuk.

Tabel 3. Tingkat Penerimaan Masyarakat Kampung Deret Petogogan per RT

\begin{tabular}{|c|c|c|c|c|c|}
\hline RT & $\begin{array}{c}\text { Total } \\
\text { Sampel } \\
\text { Unit } \\
\text { Bangu } \\
\text { nan }\end{array}$ & $\begin{array}{c}\text { Klasifi } \\
\text { kasi }\end{array}$ & $\begin{array}{c}\text { Jum } \\
\text { lah }\end{array}$ & $\begin{array}{c}\text { Nilai } \\
\text { Rata- } \\
\text { rata } \\
(\%)\end{array}$ & $\begin{array}{c}\text { Klasifi } \\
\text { kasi }\end{array}$ \\
\hline 8 & 16 & Setuju & 16 & 74 & Setuju \\
\hline \multirow{3}{*}{10} & \multirow{3}{*}{16} & $\begin{array}{l}\text { Cukup } \\
\text { Setuju }\end{array}$ & 4 & \multirow{3}{*}{73,3} & \multirow{3}{*}{ Setuju } \\
\hline & & Setuju & 11 & & \\
\hline & & $\begin{array}{l}\text { Sangat } \\
\text { Setuju }\end{array}$ & 1 & & \\
\hline \multirow[t]{2}{*}{11} & \multirow[t]{2}{*}{23} & $\begin{array}{l}\text { Cukup } \\
\text { Setuju }\end{array}$ & 7 & \multirow[t]{2}{*}{71,5} & \multirow[t]{2}{*}{ Setuju } \\
\hline & & Setuju & 16 & & \\
\hline \multirow[t]{2}{*}{12} & \multirow{2}{*}{34} & $\begin{array}{l}\text { Cukup } \\
\text { Setuju }\end{array}$ & 4 & \multirow{2}{*}{71,5} & \multirow[t]{2}{*}{ Setuju } \\
\hline & & Setuju & 30 & & \\
\hline
\end{tabular}

Sumber: Hasil analisis, 2019

Menurut hasil analisis, masyarakat Kampung Deret Petogogan klasifikasi tingkat penerimaan terhadap program adalah setuju untuk keempat RT di Kampung Deret Petogogan dengan rentang nilai dari 71,5 - 74 .

Tabel 4. Tingkat Penerimaan Masyarakat Kampung Deret Kapuk per RT

\begin{tabular}{|c|c|c|c|c|c|}
\hline RT & $\begin{array}{c}\text { Total } \\
\text { Sampel } \\
\text { Unit } \\
\text { Bangu } \\
\text { nan }\end{array}$ & $\begin{array}{c}\text { Klasifi } \\
\text { kasi }\end{array}$ & $\begin{array}{l}\text { J } \\
\text { u } \\
\text { m } \\
\text { la } \\
\text { h }\end{array}$ & $\begin{array}{c}\text { Nilai } \\
\text { Rata- } \\
\text { rata } \\
(\%)\end{array}$ & $\begin{array}{c}\text { Klasifik } \\
\text { asi }\end{array}$ \\
\hline \multirow[b]{2}{*}{2} & \multirow[b]{2}{*}{12} & Setuju & 3 & \multirow[b]{2}{*}{88,3} & \multirow[b]{2}{*}{$\begin{array}{l}\text { Sangat } \\
\text { Setuju }\end{array}$} \\
\hline & & $\begin{array}{l}\text { Sangat } \\
\text { Setuju }\end{array}$ & 9 & & \\
\hline \multirow[b]{2}{*}{3} & \multirow[b]{2}{*}{25} & Setuju & 10 & \multirow[b]{2}{*}{83} & \multirow[b]{2}{*}{ Setuju } \\
\hline & & $\begin{array}{l}\text { Sangat } \\
\text { Setuju }\end{array}$ & 15 & & \\
\hline \multirow[b]{2}{*}{5} & \multirow[b]{2}{*}{25} & Setuju & 11 & \multirow[b]{2}{*}{87,8} & \multirow[b]{2}{*}{$\begin{array}{l}\text { Sangat } \\
\text { Setuju }\end{array}$} \\
\hline & & $\begin{array}{l}\text { Sangat } \\
\text { Setuju }\end{array}$ & 14 & & \\
\hline
\end{tabular}

Sumber: Hasil analisis, 2019

Menurut hasil analisis, masyarakat Kampung Deret Kapuk klasifikasi tingkat penerimaan terhadap program adalah setuju untuk RT 3 dan sangat setuju untuk RT 2 dan RT 5 dengan rentang nilai dari $83-88,3$.

\section{Analisis Tingkat Livability}

\section{1) Bobot Kriteria}

Perhitungan bobot kriteria livability didapatkan dari pendapat para ahli dengan menggunakan AHP. AHP dalam penelitian ini menggunakan 13 kriteria yang terdiri dari 1 tingkatan hierarki.

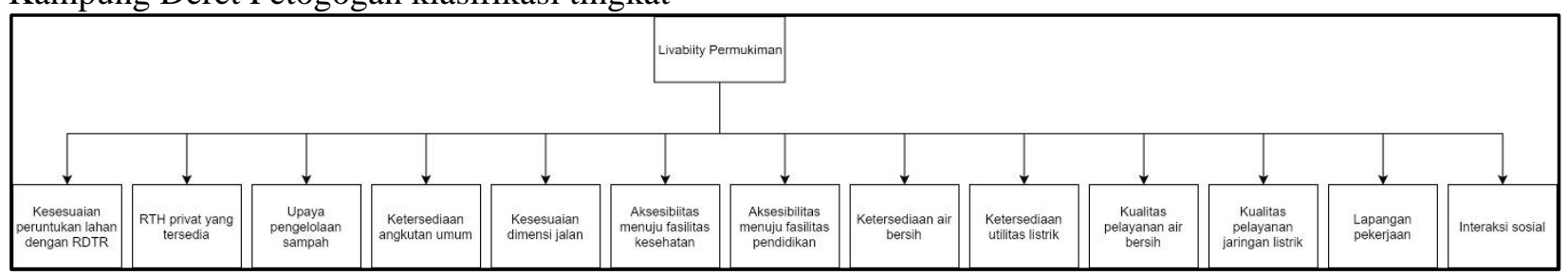

Gambar 4. Struktur Hirarki Analisis Hirarki Proses

Terdapat tiga pakar yang terlibat dalam penelitian ini dan menjadi responden dalam metode AHP. Berikut merupakan daftar responden untuk AHP livability permukiman:

1. Kepala Direktorat Pengembangan Kawasan

Permukiman Dirjen Cipta Karya

Kementerian PUPR

2. Dosen ahli arsitektur dan perencanaan Universitas Gajah Mada

3. Ahli Kebijakan Permukiman, National Affordable Housing Program World Bank
Setelah dihitung pembobotan nilai kriteria seluruh ahli dilakukan penggabungan seluruh bobot ahli dengan cara menghitung geometri dan menghasilkan bobot akhir. 
Tabel 5. Nilai Gabungan Bobot dan Rata-rata Geometri

\begin{tabular}{|c|c|c|c|c|c|}
\hline \\
\hline \multirow{2}{*}{$\begin{array}{c}\text { Kriter } \\
\text { ia }\end{array}$} & $\begin{array}{c}\text { Ahli } \\
1\end{array}$ & $\begin{array}{c}\text { Ahli } \\
2\end{array}$ & $\begin{array}{c}\text { Ahli } \\
\mathbf{3}\end{array}$ & \multirow{2}{*}{$\begin{array}{c}\text { Rata- } \\
\text { rata } \\
\text { Geometr } \\
\text { ik }\end{array}$} & \multirow{2}{*}{$\begin{array}{c}\text { Bob } \\
\text { ot } \\
\text { Fina } \\
\text { l }\end{array}$} \\
\hline & $\begin{array}{c}\text { Bob } \\
\text { ot }\end{array}$ & $\begin{array}{c}\text { Bob } \\
\text { ot }\end{array}$ & $\begin{array}{c}\text { Bob } \\
\text { ot }\end{array}$ & & \\
\hline $\mathrm{X} 1$ & 0,03 & 0,18 & 0,02 & 0,05 & $\mathbf{0 , 0 5}$ \\
\hline $\mathrm{X} 2$ & 0,02 & 0,02 & 0,04 & 0,03 & $\mathbf{0 , 0 3}$ \\
\hline $\mathrm{X3}$ & 0,04 & 0,09 & 0,06 & 0,06 & $\mathbf{0 , 0 7}$ \\
\hline $\mathrm{X4}$ & 0,05 & 0,09 & 0,02 & 0,04 & 0,05 \\
\hline $\mathrm{X5}$ & 0,04 & 0,06 & 0,01 & 0,03 & $\mathbf{0 , 0 3}$ \\
\hline X6 & 0,14 & 0,13 & 0,11 & 0,13 & 0,14 \\
\hline $\mathrm{X} 7$ & 0,12 & 0,13 & 0,08 & 0,11 & 0,12 \\
\hline $\mathrm{X8}$ & 0,27 & 0,10 & 0,25 & 0,19 & 0,21 \\
\hline X9 & 0,08 & 0,05 & 0,05 & 0,06 & $\mathbf{0 , 0 7}$ \\
\hline X10 & 0,08 & 0,05 & 0,23 & 0,10 & 0,11 \\
\hline X11 & 0,06 & 0,04 & 0,04 & 0,05 & 0,05 \\
\hline $\mathrm{X12}$ & 0,04 & 0,03 & 0,08 & 0,05 & 0,05 \\
\hline $\mathbf{X 1 3}$ & 0,03 & 0,02 & 0,02 & 0,02 & 0,03 \\
\hline $\begin{array}{c}\text { Jumla } \\
\text { h }\end{array}$ & 1,00 & 1,00 & 1,00 & $\mathbf{0 , 9 0}$ & 1,00 \\
\hline
\end{tabular}

Sumber: Hasil Analisis, 2019

\section{2) Skoring Kesesuaian Livability Permukiman}

Data yang digunakan untuk teknik skoring kesesuaian livability permukiman didapatkan dari observasi langsung yang selanjutnya dibandingkan dengan kriteria kesesuaian livability permukiman. Skor yang telah didapatkan pada masing-masing subvariabel per RT didapatkan dari frekuensi skor yang sering muncul dari masing-masing total sampel unit bangunan.

Tabel 6. Kesesuaian Skoring Tiap Aspek Livability Permukiman Kampung Deret Petogogan

\begin{tabular}{|c|c|c|c|c|c|c|c|}
\hline RT & $\mathbf{8}$ & $\mathbf{1 0}$ & $\mathbf{1 1}$ & $\mathbf{1 2}$ & $\begin{array}{c}\text { Skor } \\
\text { Total }\end{array}$ & $\begin{array}{c}\text { Skor } \\
\text { Terti } \\
\text { nggi }\end{array}$ & $\begin{array}{c}\text { Presen } \\
\text { tase } \\
\text { Kesesu } \\
\text { aian }\end{array}$ \\
\hline X1 & 2 & 2 & 2 & 2 & $\mathbf{8}$ & 12 & $\mathbf{6 7 \%}$ \\
\hline $\mathbf{X 2}$ & 2 & 2 & 1 & 1 & $\mathbf{6}$ & 12 & $\mathbf{5 0 \%}$ \\
\hline $\mathbf{X 3}$ & 1 & 1 & 1 & 1 & $\mathbf{4}$ & 12 & $\mathbf{3 3 \%}$ \\
\hline $\mathbf{X 4}$ & 2 & 2 & 2 & 2 & $\mathbf{8}$ & 12 & $\mathbf{6 7 \%}$ \\
\hline $\mathbf{X 5}$ & 2 & 2 & 2 & 2 & $\mathbf{8}$ & 12 & $\mathbf{6 7 \%}$ \\
\hline $\mathbf{X 6}$ & 2 & 2 & 2 & 2 & $\mathbf{8}$ & 12 & $\mathbf{6 7 \%}$ \\
\hline $\mathbf{X 7}$ & 1 & 1 & 1 & 1 & $\mathbf{4}$ & 12 & $\mathbf{3 3 \%}$ \\
\hline $\mathbf{X 8}$ & 3 & 3 & 3 & 3 & $\mathbf{1 2}$ & 12 & $\mathbf{1 0 0 \%}$ \\
\hline $\mathbf{X 9}$ & 3 & 3 & 3 & 3 & $\mathbf{1 2}$ & 12 & $\mathbf{1 0 0 \%}$ \\
\hline $\begin{array}{c}\mathbf{X 1} \\
\mathbf{0}\end{array}$ & 3 & 3 & 3 & 3 & $\mathbf{1 2}$ & 12 & $\mathbf{1 0 0 \%}$ \\
\hline $\begin{array}{c}\mathbf{X 1} \\
\mathbf{1}\end{array}$ & 3 & 3 & 3 & 3 & $\mathbf{1 2}$ & 12 & $\mathbf{1 0 0 \%}$ \\
\hline $\begin{array}{c}\mathbf{X 1} \\
\mathbf{2}\end{array}$ & 3 & 3 & 3 & 2 & $\mathbf{1 1}$ & 12 & $\mathbf{9 2 \%}$ \\
\hline $\begin{array}{c}\mathbf{X} 1 \\
\mathbf{3}\end{array}$ & 3 & 3 & 3 & 3 & $\mathbf{1 2}$ & 12 & $\mathbf{1 0 0 \%}$ \\
\hline
\end{tabular}

Sumber: Hasil Analisis, 2019

Setelah mengetahui skor dan bobot dari masing-masing aspek, langkah selanjutnya adalah mengalikan bobot final yang dihasilkan dari AHP dengan skor. Masing-masing unit rumah di Kampung Deret Petogogan dianalisis untuk mengetahui klasifikasi tingkat livability sehingga dapat disimpulkan secara keseluruhan dengan melihat frekuensi klasifikasi yang muncul pada masing-masing RT.

Tabel 7. Tingkat Livability Permukiman Kampung Deret Petogogan per RT

\begin{tabular}{|c|c|c|c|c|c|}
\hline RT & $\begin{array}{c}\text { Total } \\
\text { Sampel } \\
\text { Unit } \\
\text { Bangu } \\
\text { nan }\end{array}$ & $\begin{array}{c}\text { Klasifi } \\
\text { kasi }\end{array}$ & $\begin{array}{l}\text { Jum } \\
\text { lah }\end{array}$ & $\begin{array}{c}\text { Nilai } \\
\text { Rata } \\
- \\
\text { rata }\end{array}$ & $\begin{array}{c}\text { Klasifi } \\
\text { kasi }\end{array}$ \\
\hline \multirow[b]{2}{*}{8} & \multirow[b]{2}{*}{16} & Tinggi & 11 & \multirow[b]{2}{*}{2,35} & \multirow[b]{2}{*}{ Tinggi } \\
\hline & & $\begin{array}{l}\text { Sangat } \\
\text { Tinggi }\end{array}$ & 5 & & \\
\hline \multirow[b]{2}{*}{10} & \multirow[b]{2}{*}{16} & Tinggi & 15 & \multirow[b]{2}{*}{2,35} & \multirow[b]{2}{*}{ Tinggi } \\
\hline & & $\begin{array}{l}\text { Sangat } \\
\text { Tinggi }\end{array}$ & 1 & & \\
\hline \multirow[b]{2}{*}{11} & \multirow[b]{2}{*}{23} & Tinggi & 22 & \multirow[b]{2}{*}{2,32} & \multirow[b]{2}{*}{ Tinggi } \\
\hline & & $\begin{array}{l}\text { Sangat } \\
\text { Tinggi }\end{array}$ & 1 & & \\
\hline \multirow[b]{2}{*}{12} & \multirow[b]{2}{*}{34} & Tinggi & 29 & \multirow[b]{2}{*}{2,27} & \multirow[b]{2}{*}{ Tinggi } \\
\hline & & $\begin{array}{l}\text { Sangat } \\
\text { Tinggi }\end{array}$ & 5 & & \\
\hline
\end{tabular}

Sumber: Hasil Analisis, 2019

Klasifikasi yang paling banyak muncul adalah klasifikasi tinggi di setiap RT. Keempat RT yang ada di Kampung Deret Petogogan mempunyai nilai pembentuk livability permukiman yang klasifikasinya adalah tinggi dengan rentang nilai $2,27-2,35$.

Tabel 8. Rata-rata Skoring Tiap Aspek Livability Permukiman Kampung Deret Kapuk

\begin{tabular}{|c|c|c|c|c|c|c|}
\hline RT & $\mathbf{2}$ & $\mathbf{3}$ & $\mathbf{5}$ & $\begin{array}{c}\text { Skor } \\
\text { Total }\end{array}$ & $\begin{array}{c}\text { Skor } \\
\text { Tertinggi }\end{array}$ & $\begin{array}{c}\text { Presentase } \\
\text { Kesesuaian }\end{array}$ \\
\hline X1 & 1 & 1 & 1 & $\mathbf{3}$ & 9 & $\mathbf{3 3 \%}$ \\
\hline $\mathbf{X 2}$ & 2 & 1 & 1 & $\mathbf{4}$ & 9 & $\mathbf{4 4 \%}$ \\
\hline $\mathbf{X 3}$ & 2 & 1 & 2 & $\mathbf{5}$ & 9 & $\mathbf{5 6 \%}$ \\
\hline $\mathbf{X} 4$ & 2 & 2 & 2 & $\mathbf{6}$ & 9 & $\mathbf{6 7 \%}$ \\
\hline $\mathbf{X 5}$ & 2 & 2 & 2 & $\mathbf{6}$ & 9 & $\mathbf{6 7 \%}$ \\
\hline X6 & 2 & 2 & 2 & $\mathbf{6}$ & 9 & $\mathbf{6 7 \%}$ \\
\hline $\mathbf{X 7}$ & 1 & 1 & 1 & $\mathbf{3}$ & 9 & $\mathbf{3 3 \%}$ \\
\hline $\mathbf{X 8}$ & 3 & 3 & 3 & $\mathbf{9}$ & 9 & $\mathbf{1 0 0 \%}$ \\
\hline $\mathbf{X 9}$ & 3 & 3 & 3 & $\mathbf{9}$ & 9 & $\mathbf{1 0 0 \%}$ \\
\hline $\mathbf{X 1 0}$ & 3 & 3 & 3 & $\mathbf{9}$ & 9 & $\mathbf{1 0 0 \%}$ \\
\hline $\mathbf{X 1 1}$ & 3 & 3 & 3 & $\mathbf{9}$ & 9 & $\mathbf{1 0 0 \%}$ \\
\hline $\mathbf{X 1 2}$ & 3 & 3 & 3 & $\mathbf{9}$ & 9 & $\mathbf{1 0 0 \%}$ \\
\hline $\mathbf{X 1 3}$ & 3 & 3 & 3 & $\mathbf{9}$ & 9 & $\mathbf{1 0 0 \%}$ \\
\hline
\end{tabular}

Sumber: Hasil Analisis, 2019 
Setelah mengetahui skor dan bobot dari masing-masing aspek, langkah selanjutnya adalah mengalikan bobot final yang dihasilkan dari AHP dengan skor. Masing-masing unit rumah di Kampung Deret Kapuk dianalisis untuk mengetahui klasifikasi tingkat livability sehingga dapat disimpulkan secara keseluruhan dengan melihat frekuensi klasifikasi yang muncul pada masing-masing RT.

Tabel 9. Tingkat Livability Permukiman Kampung Deret Kapuk per RT

\begin{tabular}{|c|c|c|c|c|c|}
\hline RT & $\begin{array}{c}\text { Total } \\
\text { Sampel } \\
\text { Unit } \\
\text { Bangu } \\
\text { nan }\end{array}$ & $\begin{array}{c}\text { Klasifi } \\
\text { kasi }\end{array}$ & $\begin{array}{c}\text { Juml } \\
\text { ah }\end{array}$ & $\begin{array}{c}\text { Nilai } \\
\text { Rata- } \\
\text { rata }\end{array}$ & $\begin{array}{l}\text { Klasi } \\
\text { fikasi }\end{array}$ \\
\hline \multirow[b]{2}{*}{2} & \multirow[b]{2}{*}{12} & Tinggi & 11 & \multirow[b]{2}{*}{2,37} & \multirow[b]{2}{*}{$\begin{array}{c}\text { Tingg } \\
\mathrm{i}\end{array}$} \\
\hline & & $\begin{array}{l}\text { Sangat } \\
\text { Tinggi }\end{array}$ & 1 & & \\
\hline \multirow[b]{2}{*}{3} & \multirow[b]{2}{*}{25} & Tinggi & 21 & \multirow[b]{2}{*}{2,27} & \multirow{2}{*}{$\underset{\mathrm{i}}{\text { Ting }}$} \\
\hline & & $\begin{array}{l}\text { Sangat } \\
\text { Tinggi }\end{array}$ & 4 & & \\
\hline \multirow[b]{2}{*}{5} & \multirow[b]{2}{*}{25} & Tinggi & 20 & \multirow[b]{2}{*}{2,34} & \multirow{2}{*}{$\underset{\mathrm{i}}{\text { Tingg }}$} \\
\hline & & $\begin{array}{l}\text { Sangat } \\
\text { Tinggi }\end{array}$ & 5 & & \\
\hline
\end{tabular}

Sumber: Hasil Analisis, 2019

Klasifikasi yang paling banyak muncul adalah klasifikasi tinggi di setiap RT. Keempat RT yang ada di Kampung Deret Petogogan mempunyai nilai pembentuk livability permukiman yang klasifikasinya adalah tinggi dengan rentang nilai $2,27-2,37$.

\section{Analisis Hubungan Tingkat Penerimaan Masyarakat dengan Tingkat Livability Permukiman}

Untuk mengidentifikasi hubungan antara kedua variabel adalah dengan cara membandingkan keduanya untuk mengetahui hubungan dengan menggunakan crosstab dan analisis chi square. Penelitian ini mencari hubungan antara tingkat penerimaan masyarakat dan tingkat livability permukiman per masingmasing unit rumah dengan jumlah sampel yaitu sebesar 89 unit rumah untuk Kampung Deret Petogogan dan 62 unit rumah untuk Kampung Deret Kapuk.

Analisis chi square menghasilkan bahwa Kampung Deret Petogogan memperoleh X hitung sebesar 7,47. Taraf signifikansi yang digunakan adalah 0,05 dan $\mathrm{db}$ adalah 2 maka didapatkan $\mathrm{x}$ tabel sebesar 5,991. Maka disimpulkan bahwa x hitung lebih besar dari $\mathrm{x}$ tabel dapat diidentifikasi adanya hubungan antara tingkat penerimaan masyarakat dan tingkat livability permukiman
Kampung Deret Petogogan. Koefisien Kontingensi yang terbentuk adalah sebesar 0,28 yang dapat disimpulkan korelasi antara tingkat penerimaan masyarakat dan tingkat livability di Kampung Deret Petogogan adalah lemah.

Tingkat penerimaan masyarakat dan tingkat livability permukiman hasil akhirnya mayoritas berada pada klasifikasi kedua tertinggi yaitu klasifikasi tinggi dan setuju. Hal ini menunjukkan bahwa antara tingkat penerimaan masyarakat dan tingkat livability permukiman adalah berbanding lurus. Dapat disimpulkan apabila masyarakat penerima program mempunyai tingkat penerimaan yang tinggi, dalam hal ini antusias dan ikut andil dalam membangun dan merawat kampung atau permukiman di lingkungan sendiri, akan menghasilkan tingkat livability yang tinggi.

Sedangkan di Kampung Deret Kapuk, X hitung yang didapatkan dari perhitungan Chisquare adalah 2,61. Taraf signfikansi yang digunakan adalah $0,05 \mathrm{dan} \mathrm{db}$ adalah 1 maka didapatkan $\mathrm{x}$ tabel sebesar 3,84. Maka disimpulkan bahwa $\mathrm{x}$ hitung lebih kecil dari $\mathrm{x}$ tabel dapat diidentifikasi tidak adanya hubungan antara tingkat penerimaan masyarakat dan tingkat livability permukiman Kampung Deret Kapuk.

Hal ini dikarenakan pada kenyataannya masyarakat mempunyai tingkat penerimaan yang tinggi terhadap program, namun tingkat livability yang ada tidak sejalan dengan tingkat penerimaan. Hal ini dapat diartikan bahwa tingkat penerimaan masyarakat terhadap program Kampung Deret tidak ditentukan oleh tingkat livability permukimannya. Sub variabel tingkat livability yang paling memengaruhi di Kampung Deret Kapuk adalah kesesuaian peruntukan lahan dengan RDTR (X1) karena nilai yang didapatkan untuk seluruh unit rumah adalah paling rendah dan merupakan sub variabel yang paling signifikan membedakan antara Kampung Deret Petogogan dan Kampung Deret Kapuk. Kampung Deret Kapuk yang berada pada kode G.1 tidak memengaruhi persepsi masyarakat mengenai tingkat penerimaan masyarakat terhadap program Kampung Deret. Masyarakat tetap menginginkan rumahnya diperbaiki melalui program Kampung Deret.

\section{KESIMPULAN}

Tujuan pertama digambarkan bahwa masyarakat bersedia untuk permukimannya diperbaiki melalui program Kampung Deret. Selain itu, guna menjaga fasilitas yang sudah diberikan oleh pemerintah dalam program Kampung Deret, masyarakat membentuk Paguyuban Kampung Deret sebagai kelompok 
masyarakat yang bertanggung jawab atas fasilitas yang telah diberikan oleh pemerintah. Namun pemerintah menurunkan kepercayaan masyarakat karena tidak memberikan jaminan kepemilikan rumah yang sudah dijanjikan di awal program Kampung Deret dilaksanakan. Penerimaan masyarakat di Kampung Deret Kapuk juga tinggi, ditandai dengan masyarakat menghadiri sosialisasi dengan pemerintah langsung serta pihak berwenang setempat untuk mendiskusikan pelaksanaan program Kampung Deret. Namun masyarakat cenderung hanya terlibat untuk perbaikan rumah pribadi dan kurang keterlibatan untuk program Kampung Deret secara menyeluruh ditandai dengan setelah berjalannya program tersebut, tidak ada bentuk tanggung jawab yang berarti dari masyarakat untuk menjaga fasilitas yang diberikan oleh program Kampung Deret. Penilaian tingkat penerimaan masyarakat yang dilakukan di kedua kampung dilakukan dengan penyebaran kuesioner kepada masyarakat yang berisi pertanyaan setiap indikator. Selanjutnya diperoleh klasifikasi setuju untuk keseluruhan Kampung Deret Petogogan dengan rentang nilai $71,5-74$. Tingkat penerimaan masyarakat di Kampung Deret Kapuk memperoleh klasifikasi sangat setuju secara keseluruhan di Kampung Deret Kapuk dengan rentang nilai $83-88,3$.

Tingkat livability permukiman yang diperoleh di kedua kampung didapatkan dengan observasi langsung dengan menyesuaikan kondisi eksisting dengan standar setiap subvariabel yang ada dengan teknik skoring. Setelah hasil skoring didapatkan, lalu dikalikan dengan bobot dari penilaian tiga ahli. Tingkat livability melibatkan analisis hirarki proses dalam prosesnya untuk mencari bobot pada setiap subvariabel. Bobot tertinggi yang dihasilkan pada analisis hirarki proses adalah aspek ketersediaan air bersih (X8) dengan nilai 0,21 dan bobot terendah yaitu aspek RTH privat yang tersedia (X2), kesesuaian dimensi jalan (X5), dan interaksi sosial (X3) dengan masing-masing nilai per aspek adalah 0,03 . Penilaian tingkat livability permukiman memperoleh klasifikasi tinggi secara keseluruhan di kedua kampung dengan rentang nilai 2,27 2,35 untuk Kampung Deret Petogogan dan nilai 2,27 - 2,37 untuk Kampung Deret Kapuk.

Tujuan terakhir didapatkan dua hasil yang berbeda antara kedua kampung yang diteliti. Kampung Deret Petogogan diperoleh hasil adanya hubungan antara tingkat penerimaan masyarakat dengan tingkat livability permukiman dikarenakan $\mathrm{x}$ hitung yang bernilai 7,47 yang mana mempunyai nilai lebih besar dari $\mathrm{x}$ tabel. Kuat hubungan yang diidentifikasi dengan koefisien kontingensi adalah sebesar 0,28 yang dapat disimpulkan hubungan yang terjadi adalah lemah. Tingkat penerimaan masyarakat dan tingkat livability permukiman hasil akhirnya mayoritas berada pada klasifikasi kedua tertinggi yaitu klasifikasi tinggi dan setuju. Hal ini menunjukkan bahwa antara tingkat penerimaan masyarakat dan tingkat livability permukiman adalah berbanding lurus. Dapat disimpulkan apabila masyarakat penerima program mempunyai tingkat penerimaan yang tinggi, dalam hal ini antusias dan ikut andil dalam membangun dan merawat kampung atau permukiman di lingkungan sendiri, akan menghasilkan tingkat livability yang tinggi.

Sedangkan di Kampung Deret Kapuk tidak teridentifikasi adanya hubungan antara tingkat penerimaan dan tingkat livability permukiman dikarenakan $\mathrm{x}$ hitung yang bernilai 2,61 yang mana mempunyai nilai lebih kecil dari $\mathrm{x}$ tabel. Hal ini dapat diartikan bahwa tingkat penerimaan masyarakat terhadap program Kampung Deret tidak ditentukan oleh tingkat livability permukimannya. Sub variabel tingkat livability yang paling memengaruhi di Kampung Deret Kapuk adalah kesesuaian peruntukan lahan dengan RDTR (X1) karena nilai yang didapatkan untuk seluruh unit rumah adalah paling rendah dan merupakan sub variabel yang paling signifikan membedakan antara Kampung Deret Petogogan dan Kampung Deret Kapuk. Kampung Deret Kapuk yang berada pada kode G.1 tidak memengaruhi persepsi masyarakat mengenai tingkat penerimaan masyarakat terhadap program Kampung Deret. Masyarakat tetap menginginkan rumahnya diperbaiki melalui program Kampung Deret.

\section{DAFTAR PUSTAKA}

Fitria, N. and Setiawan, R., 2014. Identifikasi Karakteristik Lingkungan Permukiman Kumuh di Kelurahan Kapuk, Jakarta Barat. Jurnal Teknik ITS, 3(2): C240-C244. Indratno, I. dan Irwinsyah, R., 1998. Aplikasi Analisis Tabulasi Silang (Crosstab) dalam Perencanaan Wilayah dan Kota.Jurnal $P W K-48,9$.

Irfan, Maulana. 2016. Metamorfosis Gotong Royong Dalam Pandangan Konstruksi Sosial. Prosiding Penelitian dan Pengabdian kepada Masyarakat, 4(1): 1140.

Janah L., 2014. Statistik Sosial. Modul SOSI 4414: 1-34.

Joubert, M.D. and Prihantoko, A., 2015. Analisis Keberterimaan Pengguna terhadap Aplikasi Sistem Manajemen Operasi Irigasi 
menggunakan Technology Acceptance Model (Studi Kasus Daerah Irigasi Boro, Purworejo). Jurnal Irigasi, 10(1): 11-20.

Keman, S., 2005. Kesehatan perumahan dan lingkungan pemukiman. Jurnal Kesehatan Lingkungan, 2(1).

Makkasau, K., 2013. Penggunaan metode Analytic Hierarchy Process (AHP) dalam penentuan prioritas program kesehatan (studi kasus program Promosi Kesehatan).J@TI UNDIP: Jurnal Teknik Industri, 7(2): 105-112.

Muhdar, 2015. Potret Ketenagakerjaan, Pengangguran, Dan Kemiskinan Di Indonesia: Masalah dan Solusi, 11(1): 4266.

Muttaqin, Dani. 2010. Most Livable City Index, Tantangan Menuju Kota Layak Huni. Kementrian Agraria dan Tata Ruang. Jakarta.

Pemerintah Daerah Provinsi DKI Jakarta. 2012. Perda Provinsi DKI Jakarta No. 1 Tahun 2012 Tentang Rencana Tata Ruang Wilayah 2030. Lembaran Daerah Provinsi Daerah Khusus Ibukota Jakarta Tahun 2012 Nomor 1. Jakarta: Sekretariat Daerah Provinsi DKI Jakarta.
Pemerintah Daerah Provinsi DKI Jakarta. 2013. Peraturan Gubernur Provinsi DKI Jakarta Nomor 64 Tahun 2013 Tentang Bantuan Perbaikan Rumah di Permukiman Kumuh Melalui Penataan Kampung. Jakarta: Sekretariat Daerah Provinsi DKI Jakarta.

Pemerintah Daerah Provinsi DKI Jakarta. 2014. Perda Provinsi DKI Jakarta No. 1 Tahun 2014 Tentang Rencana Detail Tata Ruang dan Peraturan Zonasi. Lembaran Daerah Provinsi Daerah Khusus Ibukota Jakarta Tahun 2014 Nomor 301. Jakarta: Sekretariat Daerah Provinsi DKI Jakarta.

Pemerintah Indonesia. 2011. Undang-Undang No. 1 Tahun 2011 tentang Perumahan dan Kawasan Permukiman. Lembaran Negara Republik Indonesia Tahun 2011 Nomor 7. Jakarta: Sekretariat Negara.

Setiadi, H.A. dan Rahman, A.P., 2016. Analisa Keberhasilan Program Kampung Deret Petogogan Menggunakan Pendekatan Evaluasi Pasca Huni. Jurnal Sosial Ekonomi Pekerjaan Umum, 8(1): 51-61. 
HUBUNGAN TINGKAT PENERIMAAN MASYARAKAT DENGAN LIVABILITY PERMUKIMAN KAMPUNG DERET PETOGOGAN DAN KAMPUNG DERET KAPUK 